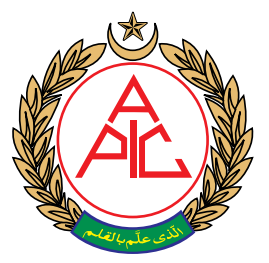

\title{
Awareness and practice of patient's oral care among critical care nurses in a rural tertiary care hospital
}

\author{
Singla Bhavika, Akshaya N. Shetti, Rachita Mustilwar, Singla Anshul
}

\begin{abstract}
Singla Bhavika, Assistant Professor, Department of Anesthesiology, RMC, Loni, Maharashtra 413736, India Akshaya N Shetti, Professor, Department of Anesthesiology, RMC, Loni, Maharashtra 413736, India

Rachita Mustilwar, Lecturer, Department of Periodontology, RDC, Loni, Maharashtra 413736, India

Singla Anshul, Assistant Professor, Department of Head and Neck Surgical Oncology, $\mathrm{HBCH}$, Sangrur, India

Correspondence:

Dr Akshaya N. Shetti

Department of Anesthesiology, Rural Medical College - Pravara Institute of Medical Sciences, A/p: Loni, Tal:Rahata Dist:Ahmednagar,

(Maharashtra) 413736 India

E-mail: aksnsdr@gmail.com; Phone:917507807673

Received: 17 April 2019,

Reviewed: 27 May, 4 June 2019,

Revised: 9 June 2019,

Reviewed: 10, 12 June 2019,

Accepted: 01 August 2019
\end{abstract}

\section{INTRODUCTION}

Oral care forms an important part of the patientcare in a hospital set up. This specially holds true in critical care units (CCU), where patients are unable to self-provide oral care and hence, depend on care givers to anticipate needs and are at greater risk for worsening oral health if staff performs inadequate oral care. The condition of mouth is one of the best indices of quality of nursing care. ${ }^{1}$ care unit (CCU) nurses.

\section{ABSTRACT}

$\overline{\text { Background and aim: Oral care contributes significantly to the patients' health outcome }}$ in a critical care unit. Nurses play a vital role in maintaining good oral health. However, there remains a dearth of literature regarding oral care practices among nurses working in an Indian critical care unit. In this descriptive cross sectional study, we assessed the level of awareness and the existing practices of patients' oral care among our critical

Methodology: After obtaining approval from the institutional ethics committee, 64 CCU nurses, having work experience of atleast 6 months in the CCU, were enrolled in this descriptive cross sectional study. A self-structured questionnaire was used to assess the awareness and practice of the nurses. The data collected was analyzed using descriptive statistics and results were expressed as percentages.

Result: Of the 64 nurses enrolled in the study, there were no dropouts. It was found that $62(96.87 \%)$ nurses provided oral care to all the CCU patients. 60 (93.7\%) nurses claimed that a standard oral care protocol has been provided to them. Documentation of the oral care was carried out by 54 (84.37\%) nurses. Although $50 \%$ of the nurses had been trained to provide oral care, 54 (84.37\%) nurses felt the need of fresh training. 60 (93.7\%) nurses preferred using toothbrush in conscious patients. Chlorhexidine was the most commonly used solution. Bleeding, extubation and biting were among the few complications that they faced during routine oral care.

Conclusion: Despite working in a rural set up with limited resources available, oral care was provided by most of the nurses. Following a standard protocol and documentation of the same, has helped maintain consistency in oral care of all critical care patients.

Key words: Oral health; Awareness; Critical care; Nursing; Rural.

Citation: Bhavika S, Shetti AN, Mustilwar R, Anshul S. Awareness and practice of patient's oral care among critical care nurses in a rural tertiary care hospital. Anaesth pain \& intensive care 2019;23(3):295-300
The poor oral health among intensive care unit (ICU) patients acts as a source of increasing bacterial virulence of oro-pharyngeal secretions and subsequent development of nosocomial pneumonias. ${ }^{2}$

A rural area in India means a low density population area with limited resources unlike in big towns. The study was conducted in a rural tertiary care hospital, which serves a total population of 13,000 of the nearby villages. Limited access to oral health services and non-availability of advanced oral care equipment for 
the nurses might lead to inconsistent implementation of oral care of patients in rural healthcare set up. Oral hygiene practices and procedures with a focus on nurse-provided oral care have been considered in a number of studies. ${ }^{3,4}$ However, only a limited number of studies are available about the oral care practices among nurses working in a rural hospital CCU. Therefore, this study was conducted with an aim to assess the awareness and practice of patients' oral care among rural tertiary CCU nurses.

\section{METHODOLOGY}

After obtaining the Institutional Ethical Committee (IEC) approval (Registration No.-PIMS/DR/ RMC/2018/262), 64 nurses working in an adult CCU of our hospital, having work experience of at least 6 months in the CCU, were enrolled in this descriptive cross-sectional study. A written informed consent was taken and nurses not willing to participate in the study were excluded.

The data collection was performed using a selfstructured questionnaire, comprising of 22 questions, divided into two parts. Part A consisted of five questions and included the socio-demographic profile of the participants. Part B included 17 questions pertaining to the awareness and practice of nurses regarding patients' oral care. In order to eliminate misunderstandings in the questionnaire and to ensure that important details would not be missed, the questionnaire was validated by two senior intensivists who were not a part of the study. A sample size of convenience was used and the data was collected over a period of one month.

Statistical analysis: The data collected was analyzed by descriptive statistics and the statistical analysis was performed using the computer program SPSS (Statistical Package for Social Sciences, version 15.0). The results were expressed as percentages.

\section{RESULTS}

A total of 64 nurses participated in the study and there were no dropouts. The socio-demographic profile of the nurses has been shown in Table 1 . Of the 64 nurses, majority were males $(65.6 \%)$. Majority of the nurses were diploma holders $(62.5 \%)$ and had more than one year of working experience $(65.6 \%)$ in intensive care units (ICU).

The results of oral care awareness and practice among nurses are depicted in Table 2. Majority of the nurses believed that good oral care has an important role in patient's clinical outcome (90.6\%). The results showed that more than $90 \%$ of the nurses implemented oral care to their patients, whether or not mechanically ventilated. Of all the participants,
Table 1: Socio-demographic profile of nurses Variable \begin{tabular}{l|l} 
Frequency & Percentage
\end{tabular} Gender

\begin{tabular}{l|l|l}
\hline Male & 42 & 65.6 \\
\hline Female & 22 & 34.4 \\
\hline
\end{tabular}

Age (in years)

\begin{tabular}{l|l|l}
\hline$\leq 20$ & 02 & 3.1 \\
\hline $21-29$ & 50 & 78 \\
\hline $30-39$ & 06 & 9.3 \\
\hline $40-49$ & 06 & 9.3 \\
\hline \multicolumn{3}{|l}{ Level of Education } \\
\hline Diploma & 40 & 62.5 \\
\hline Degree & 22 & 34.4 \\
\hline Masters & 02 & 3.1 \\
\hline
\end{tabular}

Shift Pattern

\begin{tabular}{l|c|c}
\hline Morning & 10 & 15.6 \\
\hline Evening & 04 & 6.3 \\
\hline Night & 08 & 12.5 \\
\hline Rotation & 42 & 65.6 \\
\hline
\end{tabular}

Work Experience In Intensive Care Unit

\begin{tabular}{l|l|l}
\hline $6 m-1 \mathrm{y}$ & 22 & 34.4 \\
\hline$>1 \mathrm{y}-5 \mathrm{y}$ & 28 & 43.8 \\
\hline$>5 \mathrm{y}$ & 14 & 21.8 \\
\hline
\end{tabular}

majority were using personal protective devices and performing hand hygiene prior to providing oral care to the patients.

Regarding training in providing oral care, $50 \%$ of the nurses claimed to have attained training. Despite this, almost $84 \%$ of the nurses felt that training in oral care implementation would be helpful. Over half of the nurses $(68 \%)$ spent two to five minutes in providing oral care to their patients. Interestingly, almost $84 \%$ nurses carried out oral care documentation of the patients. Of the participants, 93\% claimed that a standard oral care protocol has been provided to them (Table 2).

$90 \%$ of the nurses took care of all the components of mouth, including lips, gums, mucosa, tongue and teeth. It was found that toothbrush was the most commonly used equipment for oral care in non-ventilated patients. In case of mechanically ventilated patients, $93 \%$ of the nurses preferred using forceps and gauze. The other tools used were tongue depressor and oral suction. Among the solutions used, chlorhexidine was preferred by almost $78 \%$ of the nurses. Normal saline, tap water and glycerin were amongst the other solutions used for oral care by the critical unit nurses.

A number of factors were acknowledged as the 
original article

Table 2: Awareness and practice of oral care

\begin{tabular}{|c|c|c|c|c|}
\hline No. & Variable & Category & Frequency & Percentage \\
\hline \multirow[t]{2}{*}{1.} & \multirow{2}{*}{$\begin{array}{l}\text { Do you believe } \\
\text { good oral care } \\
\text { is important for } \\
\text { patients' clinical } \\
\text { outcome? }\end{array}$} & Yes & 58 & 90.6 \\
\hline & & No & 06 & 9.4 \\
\hline \multirow[t]{5}{*}{2.} & \multirow{2}{*}{$\begin{array}{l}\text { Training attained in } \\
\text { providing oral care? }\end{array}$} & Yes & 32 & 50 \\
\hline & & No & 32 & 50 \\
\hline & \multirow{3}{*}{$\begin{array}{l}\text { If yes, how long } \\
\text { ago was training } \\
\text { obtained? }\end{array}$} & $<2 y$ & 14 & 43.7 \\
\hline & & $2-5 y$ & 08 & 25 \\
\hline & & $>5 y$ & 10 & 31.2 \\
\hline \multirow[t]{3}{*}{3.} & \multirow{3}{*}{$\begin{array}{l}\text { Is training in oral } \\
\text { care required? }\end{array}$} & Yes & 54 & 84.4 \\
\hline & & No & 04 & 6.2 \\
\hline & & May be & 06 & 9.3 \\
\hline \multirow[t]{2}{*}{4.} & \multirow{2}{*}{$\begin{array}{l}\text { Is oral care provided } \\
\text { to all ICU patients } \\
\text { (whether or not on } \\
\text { ventilation)? }\end{array}$} & Yes & 62 & 96.9 \\
\hline & & No & 02 & 3.1 \\
\hline \multirow[t]{2}{*}{5.} & \multirow{2}{*}{$\begin{array}{l}\text { Is hand hygiene } \\
\text { performed prior to } \\
\text { providing oral care? }\end{array}$} & Yes & 60 & 93.7 \\
\hline & & No & 04 & 6.3 \\
\hline \multirow[t]{3}{*}{6.} & \multirow{3}{*}{$\begin{array}{l}\text { Use of personal } \\
\text { protective devices } \\
\text { while performing } \\
\text { oral care? }\end{array}$} & Yes & 62 & 96.9 \\
\hline & & No & 0 & 0 \\
\hline & & Sometimes & 02 & 3.1 \\
\hline \multirow[t]{2}{*}{7.} & \multirow{2}{*}{$\begin{array}{l}\text { Are you comfortable } \\
\text { providing oral care } \\
\text { to patients? }\end{array}$} & Yes & 60 & 93.7 \\
\hline & & No & 04 & 6.3 \\
\hline \multirow[t]{4}{*}{8.} & \multirow{4}{*}{$\begin{array}{l}\text { How much time is } \\
\text { spent in performing } \\
\text { oral care }\end{array}$} & $\leq 1 \min$ & 04 & 6.3 \\
\hline & & $2-5 \min$ & 44 & 68.7 \\
\hline & & $6-10 \mathrm{~min}$ & 12 & 18.7 \\
\hline & & $>10 \min$ & 04 & 6.3 \\
\hline \multirow[t]{2}{*}{9.} & \multirow{2}{*}{$\begin{array}{l}\text { Are equipments } \\
\text { cleaned after oral } \\
\text { care? }\end{array}$} & Yes & 64 & 100 \\
\hline & & No & 0 & 0 \\
\hline \multirow[t]{2}{*}{10.} & \multirow{2}{*}{$\begin{array}{l}\text { Is documentation } \\
\text { carried out after } \\
\text { providing oral care? }\end{array}$} & Yes & 54 & 84.8 \\
\hline & & No & 10 & 15.6 \\
\hline \multirow[t]{2}{*}{11.} & \multirow{2}{*}{$\begin{array}{l}\text { Have you been } \\
\text { provided with a } \\
\text { standard oral care } \\
\text { protocol? }\end{array}$} & Yes & 60 & 93.7 \\
\hline & & No & 04 & 6.3 \\
\hline
\end{tabular}

barriers in providing oral care by the nurses. More than $50 \%$ of nurses found that non-cooperation of patient and endotracheal tube displacement were the main problems faced by them. Other factors like lack of knowledge and time constraint were also addressed by few nurses. Amongst the complications encountered while performing oral care, bleeding was the most common (expressed by $70 \%$ nurses), followed by extubation, biting and agitation.
(Table 2 Contd)

\begin{tabular}{|c|c|c|c|c|}
\hline \multirow[t]{5}{*}{12.} & \multirow{5}{*}{$\begin{array}{l}\text { Which components } \\
\text { are taken care of } \\
\text { while providing oral } \\
\text { care }\end{array}$} & Lips & 62 & 96.8 \\
\hline & & $\begin{array}{l}\text { Gums \& } \\
\text { mucosa }\end{array}$ & 60 & 93.7 \\
\hline & & Tongue & 64 & 100 \\
\hline & & Teeth & 64 & 100 \\
\hline & & $\begin{array}{l}\text { All of the } \\
\text { above }\end{array}$ & 58 & 90.6 \\
\hline \multirow[t]{3}{*}{13.} & \multirow{3}{*}{$\begin{array}{l}\text { Equipments/tools } \\
\text { used in non- } \\
\text { ventilated patients }\end{array}$} & Toothbrush & 44 & 68.7 \\
\hline & & $\begin{array}{l}\text { Manual care } \\
\text { (with fingers) }\end{array}$ & 04 & 6.3 \\
\hline & & Both & 16 & 25 \\
\hline \multirow[t]{3}{*}{14.} & \multirow{3}{*}{$\begin{array}{l}\text { Equipments/tools } \\
\text { used in ventilated } \\
\text { patients }\end{array}$} & $\begin{array}{l}\text { Forceps and } \\
\text { gauze }\end{array}$ & 60 & 93.7 \\
\hline & & $\begin{array}{c}\text { Tongue } \\
\text { depressor }\end{array}$ & 40 & 62.3 \\
\hline & & Oral suctioning & 28 & 43.7 \\
\hline \multirow[t]{6}{*}{15.} & \multirow{6}{*}{$\begin{array}{l}\text { Solutions/materials } \\
\text { used for oral care }\end{array}$} & Normal saline & 14 & 21.8 \\
\hline & & Water & 26 & 40.6 \\
\hline & & Toothpaste & 08 & 12.5 \\
\hline & & Chlorhexidine & 50 & 78.1 \\
\hline & & Glycerin & 12 & 18.7 \\
\hline & & Sodium bicarb & 02 & 3.1 \\
\hline \multirow[t]{5}{*}{16.} & \multirow{5}{*}{$\begin{array}{l}\text { Barriers/problems } \\
\text { faced while } \\
\text { providing oral care }\end{array}$} & $\begin{array}{l}\text { Uncooperative } \\
\text { patient }\end{array}$ & 52 & 81.2 \\
\hline & & $\begin{array}{l}\text { Tube } \\
\text { displacement } \\
\text { (intubated } \\
\text { patients) }\end{array}$ & 42 & 65.6 \\
\hline & & $\begin{array}{c}\text { Time } \\
\text { constraint }\end{array}$ & 08 & 12.5 \\
\hline & & $\begin{array}{c}\text { Lack of } \\
\text { knowledge }\end{array}$ & 10 & 15.6 \\
\hline & & $\begin{array}{l}\text { Lack of } \\
\text { equipment }\end{array}$ & 04 & 6.2 \\
\hline \multirow[t]{4}{*}{17.} & \multirow{4}{*}{$\begin{array}{l}\text { Complications } \\
\text { encountered while } \\
\text { performing oral care }\end{array}$} & Bleeding & 46 & 71.8 \\
\hline & & Biting & 28 & 43.7 \\
\hline & & Agitation & 20 & 31.2 \\
\hline & & Extubation & 34 & 53.2 \\
\hline
\end{tabular}

\section{DISCUSSION}

Oral hygiene is a significant aspect of nursing care, especially in a CCU, where patients are unable to independently perform self-care activities such as oral care. Although a challenging task to perform, the nurses must incorporate knowledge of the patient's clinical condition, oral health status, threats and barriers to oral health, and provide comprehensive 
oral care aimed at minimizing oral health problems that impact the patient's well-being. Despite the widely acknowledged importance of oral care for critically ill patients, there is a paucity of literature on oral care and hygiene in rural set ups. Lack of proper knowledge of the nurses, resources and nonaffordability of the patients in rural areas may lead to poor oral care of the patients in such healthcare centers compared to the urban centers. This study was conducted with an aim to assess the awareness and practice of patients' oral care among rural tertiary CCU nurses.

Insufficient oral care can lead to degradation in overall gingival tissue health and the development of periodontal disease. ${ }^{2}$ This contributes to a pathogenic environment among the already critically ill. In a study by Quinn and Baker, oral hygiene showed to be a statistically significant measure in preventing hospital-acquired pneumonia in non-mechanically ventilated patients. ${ }^{5}$ In a study by Grap et al, it was found that priority level perception of oral hygiene seems to play a role in how often the oral care was performed. ${ }^{6}$ In our study, $90 \%$ of the nurses believed that good oral care has an important role in patients' clinical outcome. Similarly, Hanneman et al reported the priority rating by nurses was quite higher at 71 (based on a scale of 0 to 100 with 100 being of highest priority). ${ }^{7}$

A number of previous studies have concluded that non-dental health care professionals or nurses require training or feel the need for training in oral care, to improve their oral health knowledge. ${ }^{8-10}$ Similar results were found in our study, where more than $80 \%$ nurses felt training in oral care would be helpful.

The various structures of the mouth require combined interventions to maintain oral health, prevent conversion to an oral pathogenic state, and promote comfort for the critical patients. There is a complex integration of functional oral components necessary to maintain oral health and wellness. More than $90 \%$ nurses in our study had been taking care of all the structures of the oral cavity including the lips, mucosal lining, gingiva, teeth, saliva, and the tongue.

Various products and a combination of mechanical and pharmacological interventions have been used to provide optimal oral hygiene. The choice of these products and solutions has been examined in the literature, with the call for products like toothbrush, swabs, chlorhexidine and normal saline. ${ }^{11,12}$

Tooth brushing is widely considered to be the best method for cleaning teeth and Cochrane reviews have shown that both powered and manual tooth brushing remove dental plaque but the relative merits of different types of toothbrushes for this over time remain inconclusive. ${ }^{13}$ In our study, most of the nurses (68\%) used toothbrush for non-ventilated patients and forceps and gauze for the ventilated patients. The other tools being used were tongue depressor and oral suctioning. Most frequently used equipment found among the other studies were spatulas, toothbrushes, and gauze, foam swabs and a depressor with gauze..$^{14,15}$ Powered toothbrushes compared to foam swabs, each used for two minutes four times a day with chlorhexidine gluconate (CHX), by Needleman et al. demonstrated significant reductions of dental plaque in the powered tooth brush group. ${ }^{16}$

Use of CHX by most of our nurses (78\%) is in accordance with previous published reports that suggest CHX should be a part of the oral care protocols..$^{14,17,18}$ In a study by Tantipong et al., the incidence of VAP among patients orally swabbed with $2 \%$ CHX was $5 \%$ compared to $11 \%$ in patients receiving normal saline swabs for oral care. ${ }^{19}$ In contrast, Turk et al. found sodium bicarbonate to be the most commonly used product followed by moisturizing agents. ${ }^{20}$ Similarly, in a study on 218 critical care nurses, it was reported that most of them used gauze pads or tongue depressors for debridement and fewer than half used toothbrushes. ${ }^{21}$

Various concerns of nursing have been previously expressed. Our nurses found that tube displacement and un-cooperation were the main barriers encountered. Amongst the complications encountered were bleeding, biting, agitation and extubation. Bader et al. observed that generalized responses such as agitation, biting the ETT and coughing were frequent manifestations among intubated patients. ${ }^{22}$ The fear of dislodging the ETT has been noted to be a concern of ICU nurses when performing oral care and may account for less thorough practices as evidenced by continued use of foam swabs for routine care in other studies. ${ }^{18,23}$

Looking at the documented oral care practices in the ICU population, there was a severe lack of articles focusing on oral hygiene documentation. In a study by Adib and Ansari, oral care was documented only in $20 \%$ of cases. ${ }^{24}$ Interestingly, $84 \%$ nurses in our study carried out documentation regarding oral care provided to the patients.

There is also a paucity of literature on provision of standard oral care protocols to the nurses. In a study by Cason et al involving 1200 nurses, it was reported by half of the nurses that their workplace lacked a standard mouth care guideline. ${ }^{25}$ A similar need to design a mouth care guideline was observed by the nurses in another study by Johnstone et al. ${ }^{26}$

Future prospects:

Continued nurse education on regular intervals with respect to oral care of critically ill patients should be mandatory. Latest gadgets like powered toothbrushes have demonstrated superiority in plaque removal and 
better cleansing in gingival crevices when compared to manual tooth brushes. ${ }^{27}$ Continued research regarding safety and efficacy of oral care protocols remains an important task in an era where level of care is assessed by its quality and cost to society.

\section{CONCLUSION}

While majority of the nurses recognized the importance of oral care, they had some reluctance in intubated patients while performing oral hygiene. In our study, a satisfactory level of oral care has been provided by the nursing staff, which had adequate knowledge about its importance. We recommend that oral care protocols must be a part of care being provided in a CCU.

Conflict of interest: None declared by the authors.

Authors' contribution: All authors took equal part in conduction of the study, statistical analysis, manuscript editing and literature search 


\section{REFERENCES}

1. Henderson V. Basic Principles of Nursing Care. Geneva: International Council of Nurses;1960.

2. Paju S, Scannapieco FA. Oral biofilms, periodontitis, and pulmonary infections. Oral Dis. 2007;13(6):50812. [PubMed] DOI: $10.1111 /$ /.16010825.2007.01410a.x

3. Ibrahim SM, Mudawi AM, Omer 0. Nurses' knowledge, attitude and practice of oral care for intensive care unit patients. Open J Stomat. 2015;5(7):179-86. DOI: 10.4236/ ojst.2015.57023

4. Faragalla Al, Almaki EJ, Asiri HA. Knowledge, attitude and practice of nurses to oral health care for hospitalized patients in Abha citySaudi Arabia. Acta Scientific Dental Sci. 2018;2(5):16-23. [Free Full Text]

5. Quinn B, MSN, RN, BC, Baker DL. Comprehensive oral care prevents hospital-acquired non-ventilator pneumonia. American Nurse Today. 2015;10(3):18-23. [Free Full Text]

6. Grap MJ, Munro CL, Ashtiani B, Bryant S. Oral care interventions in critical care: frequency and documentation. Am J Crit Care. 2003;12(2):113-99. [PubMed]

7. Hanneman SK, Gusick GM. Frequency of oral care and positioning of patients in critical care: A replication study. Am J Crit Care. 2005;14(5):378-87. [PubMed]

8. Costello T, Coyne I. Nurses' knowledge of mouth care practices. Br J Nurs. 2008;17(4):264-68. [PubMed] DOI: 10.12968/bjon.2008.17.4.28716

9. Wilkin K. A critical analysis of the philosophy, knowledge and theory underpinning mouth care practice for the intensive care unit patient. Intensive Crit Care Nurs. 2002;18(3):181-8. [PubMed] DOI: 10.1016/s0964397(02)00017-4

10. Soh KL, Shariff GS, Soh KG, Abdul RR, Sharif ASS, Ong SL. Oral care practice for the ventilated patients in intensive care units: a pilot survey. J Infect Dev Ctries. 2012;6(4):333-9. [PubMed]

11. Hajibagheri A, Azizi FI. Mouth care in patients receiving mechanical ventilation: a systematic review. Nurs Midwifery Stud. 2012;1(2):51-61. [Free Full Text]

12. Atay S, Karabacak, U. Oral care in patients on mechanical ventilation in intensive care unit: literature review. Int J Res Med Sci. 2014;2(3):822-9. [Free Full Text]

13. Robinson P, Deacon SA., Deery C, Heanue M, Walmsley AD, Worthington $\mathrm{HV}$, et al. Manual versus powered toothbrushing for oral health. Cochrane Database Syst Rev. 2005 Apr 18;(2):CD002281. [PubMed] DOI: 10.1002/14651858.CD002281.pub2

14. Miranda AF, de Paula RM, de Castro Piau CG, Costa PP, Bezerra AC. Oral care practices for patients in intensive care units: A pilot survey. Indian J Crit Care Med. 2016;20(5):26773. [PubMed] DOl: 10.4103/0972$\underline{5229.182203}$

15. Ozveren H, Ozden D. Turkish nurses' attitudes and practices regarding oral care. Int $\mathrm{J}$ Nurs Knowl. 2015;26(4):163-9. [PubMed] DOI: 10.1111/2047-3095.12060

16. Needleman IG, Hirsch NP, Leemans $M$, Moles DR, Wilson M, Ready DR, et al. Randomized controlled trial of toothbrushing to reduce ventilatorassociated pneumonia pathogens and dental plaque in a critical care unit. J Clin Periodontol. 2011;38(3):24652. [PubMed] DOI: $10.1111 / \mathrm{i} .1600-$ 051X.2010.01688.X

17. Koeman $M$, van der Ven AJ, Hak $E$, Joore $H C$, Kaasjager $K$, de Smet $A G$, et al. Oral decontamination with chlorhexidine reduces the incidence of ventilator-associated pneumonia. Am J Respir Crit Care Med. 2006;173(12):1348-55. [PubMed] DOI: $10.1164 / \mathrm{rccm} .200505-8200 \mathrm{C}$

18. Sona CS, Zack JE, Schallom ME, McSweeney $M$, McMullen $K$, Coopersmith CM, et al. The impact of a simple, low-cost oral care protocol on ventilator-associated pneumonia rates in a surgical intensive care unit. J Intensive Care Med. 2009; 24(1):54-62. [PubMed] DOI: $10.1177 / 0885066608326972$
19. Tantipong $\mathrm{H}, \quad$ Morkchareonpong C, Jaiyindee S, Thamlikitkul V. Randomized controlled trial and metaanalysis of oral decontamination with $2 \%$ chlorhexidine solution for the prevention of ventilator-associated pneumonia. Infect Control Hosp Epidemiol. 2008;29(2):131-6. [PubMed] DOI: 10.1086/526438

20. Turk G, Kocacal Guler E, Eser I, Khorshid L. Oral care practices of intensive care nurses: A descriptive study. Int J Nurs Pract. 2012;18(4):347-53. [PubMed] DOl: 10.1111/j.1440-172X.2012.02045.X

21. DeKeyser Ganz F, Fink NF, Raanan 0 , Asher M, Bruttin M, Nun MB, et al. ICU nurses' oral-care practices and the current best evidence. J Nurs Scholarsh. 2009;41(2):1328. [PubMed] DOI: 10.1111/i.15475069.2009.01264.x

22. Bader MK, Littlejohns LR. AANN Core Curriculum for Neuroscience Nursing. Glenview, IL;2010.

23. Cutler CJ, Davis N. Improving oral care in patients receiving mechanical ventilation. Am J Crit Care. 2005;14(5):389-94. [PubMed]

24. Adib Hajbagheri M, Ansari A, Azizi-Fini I. Intensive care nurses' opinions and practice for oral care of mechanically ventilated pateints. Indian J Crit Care Med. 2013;17(1):23-7. [PubMed] DOI: $10.4103 / 0972-5229.112154$

25. Cason CL, Tyner T, Saunders S, Broome L. Nurses' implementation of guidelines for ventilator-associated pneumonia from the Centers for Disease Control and Prevention. Am J Crit Care. 2007;16(1):28-36. [PubMed]

26. Johnstone L, Spence D, KoziolMcClain J. Oral hygiene care in the pediatric intensive care unit: practice recommendations. Pediatr Nurs. 2010;36(2):85-96. [PubMed]

27. Terezhalmy GT, Bartizek RD, Biesbrock AR. Relative plaque removal of three toothbrushes in a nine-period crossover study. J Periodontol. 2005;76(12):2230-5. [PubMed] DOl: 10.1902/jop.2005.76.12.2230 